\title{
Effect of Polymercoat, Fungicides and Bioagent Treatment on Plant Growth, Seed Yield and Quality of Green Gram [Vigna radiata $($ L.) Wilczek]
}

\author{
H. M. Heena Kouser*, R. B. Jolli, Jagadish Hosamani and M. M. Jamadar \\ Department of Seed Science and Technology, College of Agriculture, Vijayapur, University of \\ Agricultural Sciences, Dharwad
}

\begin{tabular}{|l|}
\hline Ke y w o r d s \\
Green gram seeds, \\
Polymercoat, \\
Fungicide, Bioagent \\
\hline Article Info \\
\hline $\begin{array}{l}\text { Accepted: } \\
\text { 14 November } 2020 \\
\text { Available Online: } \\
\text { 10 December } 2020\end{array}$ \\
\hline
\end{tabular}

\begin{abstract}
A B S T R A C T
The field experiment was conducted at Regional Agricultural Research Station, Vijayapur during kharif2019-20 to know the influence of polymer coat + fungicide + bioagent on field performance of green gram. The experiment was carried out in completely randomized block design with three replications and nine treatments consisting of different seed coatings including untreated control seeds. The results of the present investigation revealed that $\mathrm{T}_{9}$ [Polymercoat @ $3 \mathrm{ml} / \mathrm{kg}$ of seeds + combi product of carbendazim 12\% and mancozeb 63\% (Saaf) @ 3 g/kg of seed + Pseudomonas fluorescens @ 30 g/kg seeds] was found to be significantly superior with respect to growth and seed yield parameters viz., field emergence $(98.67 \%)$, plant height (70.98), number of branches per plant (16.07), number of pods per plant (18.80), number of seeds per pod (12.60), seed yield per plant $(6.43 \mathrm{~g})$, seed yield per plot $(0.601 \mathrm{~kg})$ and seed yield per hectare $(695 \mathrm{~kg})$ followed by $\mathrm{T}_{8}$ (Polymercoat @ $3 \mathrm{ml} / \mathrm{kg}$ of seeds + Vitavax Power @ $3 \mathrm{~g} / \mathrm{kg}$ of seeds + Pseudomonas fluorescens @ $30 \mathrm{~g} / \mathrm{kg}$ of seeds) against untreated control $\left(\mathrm{T}_{1}\right)$. The laboratory experiment was conducted in Department of Seed Science and Technology, College of Agriculture, Vijayapur to study on seed quality parameters viz., 100 seed weight $(3.947 \mathrm{~g})$, germination percentage $(98.67 \%)$, root length $(18.18 \mathrm{~cm})$, shoot length $(16.9 \mathrm{~cm})$, seedling vigour Index (3462), seedling dry weight $(189.77 \mathrm{mg} / 10$ seedlings) and electrical conductivity $\left(0.787 \mathrm{dSm}^{-1}\right)$ which were found to be higher in seeds obtained from $T_{9}$ followed by $T_{8}$ as compared to control $\left(T_{1}\right)$ in green gram.
\end{abstract}

\section{Introduction}

Green gram [Vigna radiata (L.) Wilczek] is an important pulse crop belongs to the Leguminosae family and sub-family Papilionaceae. It is commonly referred to as mung bean, mung, moong or golden gram (John, 1991). It is one of the third most essential food legume grown in India next to pigeon pea and chickpea. Green gram output accounts for about 10-12\% of total pulse production in the country (Dolas et al., 2018a).

In Karnataka, it occupies an area of 4.15 lakh hectares contributing to total production of 1.15 lakh tonnes and an average productivity of $277 \mathrm{~kg} / \mathrm{ha}$. It is widely grown in Gadag 
district which stands first position in area (70,316 hectares) and production $(13,944 \mathrm{t})$ followed by Dharwad (26,350 ha and 8,432 t) and Bagalkote district with 51,675 ha and 4,883 tin area and production respectively (Sangamesh and Patil, 2018).

Green gram is one of India's most significant short-duration pulse crops with highly nutritious seeds that contain about $23.86 \%$ protein, $62.6 \%$ carbohydrates, $1.15 \%$ fat, $5.27 \%$ crude fibre, $3.32 \%$ ash besides rich in lysine $(436 \mathrm{mg} / \mathrm{g})$. It is also rich in minerals having $140 \mathrm{mg}$ calcium, 8.4 per cent iron, 280 $\mathrm{mg}$ phosphorous and potassium which is a good reservoir of vitamins such as thiamine $(0.621 \mathrm{mg})$, niacin $(2.251 \mathrm{mg})$, ascorbic acid $(4.8 \mathrm{mg})$, riboflavin $(0.233 \mathrm{mg})$, pantothenic acid (1.910 mg), $114 \mathrm{IU}$ vitamin A, vitamin $\mathrm{B}_{1}(0.47 \mathrm{mg})$ and vitamin $\mathrm{B}_{2}(0.39 \mathrm{mg})$ (Santhoshi et al., 2017). The protein content of green gram is moderately high in lysine (436 mg/g), an amino acid that is low in methionine-rich cereal grains, cysteine and cystine, the amino acid-bearing sulphur. It has calorific value of 334 calories per $100 \mathrm{~g}$ of edible protein (Baldev et al., 2003).

Seed treatment is a process of applying useful materials to form a continuous layer of thin coating over the seed without altering the shape or size, by employing water as the solvent. Currently seed coating polymers are being used by seed companies along with active ingredients such as fungicides and bioagents. This helps in improving the resistance of seeds towards pest and diseases in the much warranted juvenile stage, besides improves the seedling vigour (Vanangamudi et al., 2003).

Seed treatment is also required in order to enclose the protective chemicals and nutrients applied to the seeds without substantial increase in the seed size or weight without the loss of chemicals that can be achieved by polymer coating. Polymer coating enables accurate and uniform dosage of chemicals and eliminates the chemical wastage. It provides protection against stress imposed by accelerated ageing, infection by fungi and pest infestation. It enhances emergence of seedlings and plant establishment in the field. Accurate application of chemicals eliminates the wastage and polymer coat helps to make room for including all required ingredients, nutrients, protectants, plant growth promoters, hydrophobic/hydrophilic substances, oxygen suppliers etc. to be used by enclosing the seed within a thin film of biodegradable polymer. When the seed treatment chemicals are adhered to the seed, it ensures dust free handling and makes treated seed both useful and environmentally safe. Polymer coating makes sowing operation simple and easier by causing the smooth flow of seeds. Addition of colorant to the seed helps in visual monitoring of accurate placement, enhance the appearance, marketability and consumer preference. The polymer film coat can serve as a physical barrier that has been noticed to reduce the leaching of inhibitors from the seed coverings and may limit oxygen diffusion to the embryo (Vanangamudi et al., 2003).

Seed treatment with fungicide controls the external and internal seed borne pathogen and thereby acts as protective coating to prevent soil borne pathogens from seedling infections besides enhancing seed germination and seedling vigour of the host plants. Also the seed treatment with bioagents is safe, economical, eco-friendly, cheap, can be done easily with locally available materials and not harmful to seed, animals and human beings. The higher seed yield and better quality seed can be produced by treating the seeds with polymers, fungicides and bioagents.

Keeping these in view, the present investigation was carried out in green gram by 
seed treatment to determine the influence of polymer coating, fungicides and bioagents on seedling establishment, growth performance, seed yield, seed quality and productivity in field conditions.

\section{Materials and Methods}

The present investigation was conducted during kharif2019-20 in the research plots of Regional Agricultural Research Station, Vijayapur coming under Northern Dry Zone (Zone-3 and Region-II) of Karnataka and is situated at $16^{0} 49^{\prime} \mathrm{N}$ latitude, $75^{\circ} 43^{\prime} \mathrm{E}$ longitude and at an altitude of 593 mMSL. The soil of the experimental site was black clayey soil (vertisols), deep, porous in nature and well drained. The experiment consisted of nine treatment combinations was laid out in randomized block design with three replications. Seeds were sown with spacing of $30 \mathrm{~cm}$ between rows and $10 \mathrm{~cm}$ between plants. The plot size was $4.0 \times 3.0 \mathrm{~m}$.

The treatment combinations included $_{1^{-}}$ untreated control, $\mathrm{T}_{2}$ - Polymercoat @ 3 $\mathrm{ml} / \mathrm{kg}$ of seeds, $\mathrm{T}_{3}$ - carbendazim @ $2 \mathrm{~g} / \mathrm{kg}$ of seeds, $\mathrm{T}_{4}$ - carboxin $37.5 \%$ + thiram $37.5 \%$ (Vitavax Power) @ $3 \mathrm{~g} / \mathrm{kg}$ of seeds, $\mathrm{T}_{5}$ carbendazim $12 \%+$ mancozeb $63 \%$ (Saaf) @ $3 \mathrm{~g} / \mathrm{kg}$ of seeds, $\mathrm{T}_{6}$ - Polymercoat @ 3 $\mathrm{ml} / \mathrm{kg}$ of seeds + VitavaxPower @ $3 \mathrm{~g} / \mathrm{kg}$ of seeds, $\mathrm{T}_{7}$ - Polymercoat @ $3 \mathrm{ml} / \mathrm{kg}$ of seeds + Saaf@3 g/kg of seeds, T - Polymercoat@3 $\mathrm{ml} / \mathrm{kg}$ of seeds + VitavaxPower @ $3 \mathrm{~g} / \mathrm{kg}$ of seeds + Pseudomonas fluorescens@30 g/kg of seeds and $\mathrm{T}_{9}$ - Polymercoat @ $3 \mathrm{ml} / \mathrm{kg}$ of seeds + Saaf @ $3 \mathrm{~g} / \mathrm{kg}$ of seeds + Pseudomonas fluorescens @ $30 \mathrm{~g} / \mathrm{kg}$ of seeds.

The liquid Disco AG Green L-202 polymer was used for seed coating, the polymer coat was manufactured by INCOTEC, the enhancement company, Ahmedabad and fungicides (carbendazim, Vitavax Power and Saaf) were collected from the local agro chemical dealers, Vijayapur. Pseudomonas fluorescens was collected from Department of Agricultural Microbiology, College of Agriculture, Vijayapur. One kg green gram seeds were taken in three separate polythene bags and $2 \mathrm{~g}$ of carbendazim, $3 \mathrm{~g}$ of Vitavax Power and $3 \mathrm{~g}$ of Saaf were added to those polythene bags separately. Then, $3 \mathrm{ml}$ of polymer was added to the respective polythene bags as per the treatment. The polythene bags were closed tightly trapping the air in it to form a balloon, then the bags were shaken vigorously till the seeds were uniformly coated, later the treated seeds were spread on a polythene sheet to dry under the shade. At the time of sowing, these seeds were treated with $30 \mathrm{~g}$ Pseudomonas fluorescens in the form of slurry, mixed to coat the seeds uniformly and spread on a polythene sheet to dry under the shade. The dried seeds were used for sowing. Cultural operations, application of fertilizer, method of sowing, plant protection, harvesting, threshing and cleaning was carried out as per the Package of Practices of University of Agricultural Sciences, Dharwad. Five plants were selected randomly and tagged in each treatment for recording plant growth and yield parameters. The research data was statistically analyzed for interpretation by adopting the procedures as described by Sundarrajan et al., (1972).

\section{Results and Discussion}

The data on plant growth and yield parameters (Table 1) viz., field emergence, plant height, number of branches per plant, days to $50 \%$ flowering, days to maturity number of pods per plant, number of seeds per pod, seed yield per plant, seed yield per plot and seed yield per hectare indicated that all the plant growth parameters differed significantly except days to $50 \%$ flowering and days to maturity. 
Table.1 Effect of polymer coating, fungicides and bioagents on plant growth and yield parameters of green gram

\begin{tabular}{|c|c|c|c|c|c|c|c|c|c|c|}
\hline Treatments & $\begin{array}{c}\text { Field } \\
\text { emergence } \\
(\%)\end{array}$ & $\begin{array}{l}\text { Plant height } \\
\text { (cm) }\end{array}$ & $\begin{array}{l}\text { Number of } \\
\text { branches }\end{array}$ & $\begin{array}{c}\text { Days to } \\
50 \% \\
\text { flowering }\end{array}$ & $\begin{array}{l}\text { Days to } \\
\text { maturity }\end{array}$ & $\begin{array}{c}\text { Number } \\
\text { of pods/ } \\
\text { plant }\end{array}$ & $\begin{array}{c}\text { Number } \\
\text { of } \\
\text { seeds/pod }\end{array}$ & $\begin{array}{c}\text { Seed } \\
\text { yield } \\
\text { (g/plant) }\end{array}$ & $\begin{array}{c}\text { Seed } \\
\text { yield } \\
\text { (kg/plot) }\end{array}$ & $\begin{array}{c}\text { Seed } \\
\text { yield } \\
\text { (kg/ha) }\end{array}$ \\
\hline $\mathbf{T}_{1}$ & $90.67(68.58)^{*}$ & 54.18 & 8.47 & 64.00 & 100.33 & 11.60 & 8.53 & 4.20 & 0.439 & 508 \\
\hline $\mathbf{T}_{2}$ & $91.33(72.88)$ & 57.69 & 9.77 & 63.33 & 98.33 & 12.40 & 9.40 & 5.63 & 0.495 & 573 \\
\hline $\mathbf{T}_{\mathbf{3}}$ & $93.00(74.66)$ & 58.67 & 10.47 & 63.00 & 99.00 & 14.00 & 9.78 & 4.67 & 0.503 & 581 \\
\hline $\mathbf{T}_{4}$ & $93.67(75.42)$ & 59.98 & 11.18 & 63.67 & 98.33 & 14.27 & 9.80 & 4.96 & 0.545 & 630 \\
\hline $\mathbf{T}_{5}$ & $94.00(75.82)$ & 61.63 & 12.03 & 63.00 & 98.00 & 14.87 & 9.87 & 5.23 & 0.564 & 653 \\
\hline $\mathbf{T}_{6}$ & $93.67(75.42)$ & 64.17 & 13.07 & 62.67 & 99.67 & 15.93 & 10.60 & 5.46 & 0.589 & 682 \\
\hline $\mathbf{T}_{7}$ & $96.33(78.96)$ & 65.41 & 14.02 & 62.67 & 99.00 & 16.60 & 11.47 & 5.67 & 0.593 & 686 \\
\hline $\mathbf{T}_{8}$ & $97.33(80.60)$ & 67.01 & 15.2 & 61.33 & 98.67 & 17.67 & 11.60 & 6.23 & 0.599 & 692 \\
\hline $\mathbf{T}_{9}$ & 98.67 (83.37) & 70.98 & 16.07 & 61.00 & 98.00 & 18.80 & 12.60 & 6.43 & 0.601 & 695 \\
\hline Mean & $94.30(76.18)$ & 62.19 & 12.25 & 62.74 & 98.81 & 15.13 & 10.4 & 5.39 & 0.549 & 633 \\
\hline S.Em. \pm & 1.26 & 2.37 & 0.79 & 3.67 & 4.47 & 0.98 & 0.64 & 0.33 & 0.028 & 33 \\
\hline $\begin{array}{c}\text { C.D. @ } 5 \\
\%\end{array}$ & 3.77 & 7.16 & 2.38 & NS & NS & 2.94 & 1.91 & 1.01 & 0.085 & 99 \\
\hline
\end{tabular}

NS: Non-significant *Figures in the parenthesis are square root transformed values

Seed Treatments $(\mathrm{T})$

$\mathrm{T}_{1}$ :Control (untreated)

$\mathrm{T}_{4}$ : Carboxin $37.5 \%+$ Thiram $37.5 \%$ @ $\mathrm{g} / \mathrm{kg}$ of seeds (VitavaxPower)

$\mathrm{T}_{2}$ : Polymercoat @ $3 \mathrm{ml} / \mathrm{kg}$ of seeds

$\mathrm{T}_{5}$ : Carbendazim 12\% + Mancozeb 63\% (Saaf) @ $3 \mathrm{~g} / \mathrm{kg}$ of seeds

$\mathrm{T}_{3}$ : Carbendazim@ $2 \mathrm{~g} / \mathrm{kg}$ of seeds

$\mathrm{T}_{6}$ : Polymercoat @ $3 \mathrm{ml} / \mathrm{kg}+$ VitavaxPower @ $3 \mathrm{~g} / \mathrm{kg}$ of seeds

$\mathrm{T}_{7}$ : Polymercoat@3 ml / kg + Saaf@3 g/kg of seeds

Ts:Polymercoat@3 ml /kg+VitavaxPower@3 g/kg+Pseudomonas fluorescen s@30 g/kg of seeds

$\mathrm{T}_{9}$ : Polymercoat@3 ml/kg + Saaf@3 g/kg + Pseudomonas fluorescens @30 g / kg of seeds 
Table.2 Effect of polymer coating, fungicides and bioagents on seed quality parameters of green gram

\begin{tabular}{|c|c|c|c|c|c|c|c|}
\hline Treatments & $\begin{array}{l}\text { Hundred seed } \\
\text { weight (g) }\end{array}$ & $\begin{array}{c}\text { Germination } \\
\text { percentage }(\%)\end{array}$ & $\begin{array}{l}\text { Shoot length } \\
(\mathrm{cm})\end{array}$ & $\begin{array}{l}\text { Root length } \\
\text { (cm) }\end{array}$ & $\begin{array}{l}\text { Seedling vigour } \\
\text { index }\end{array}$ & $\begin{array}{l}\text { Seedling } \\
\text { dry weight } \\
\text { (mg) }\end{array}$ & $\begin{array}{c}\text { Electrical } \\
\text { conductivity }\left(\mathrm{dSm}^{-1}\right)\end{array}$ \\
\hline $\mathbf{T}_{1}$ & 3.346 & $91.67(71.89)^{*}$ & 15.69 & 16.52 & 2952 & 178.14 & 0.880 \\
\hline $\mathbf{T}_{2}$ & 3.548 & $93.33(72.55)$ & 15.90 & 16.75 & 3048 & 181.50 & 0.856 \\
\hline $\mathbf{T}_{3}$ & 3.680 & $94.67(75.05)$ & 16.08 & 16.98 & 3132 & 183.67 & 0.853 \\
\hline $\mathbf{T}_{4}$ & 3.722 & $94.33(76.24)$ & 16.25 & 17.25 & 3160 & 183.33 & 0.853 \\
\hline $\mathbf{T}_{5}$ & 3.769 & $95.33(76.87)$ & 16.31 & 17.50 & 3223 & 184.33 & 0.865 \\
\hline $\mathbf{T}_{6}$ & 3.765 & $96.33(77.00)$ & 16.56 & 17.68 & 3298 & 186.33 & 0.837 \\
\hline $\mathbf{T}_{7}$ & 3.800 & $97.33(80.64)$ & 16.67 & 17.73 & 3348 & 187.67 & 0.810 \\
\hline $\mathbf{T}_{8}$ & 3.862 & $98.33(81.26)$ & 16.83 & 18.03 & 3427 & 188.50 & 0.797 \\
\hline $\mathbf{T}_{9}$ & 3.947 & $98.67(82.67)$ & 16.91 & 18.18 & 3462 & 189.77 & 0.787 \\
\hline Mean & 3.716 & $95.56(77.13)$ & 16.35 & 17.40 & 3228 & 184.8 & 0.838 \\
\hline S.Em. \pm & 0.086 & 1.674 & 0.200 & 0.230 & 61.940 & 1.778 & 0.016 \\
\hline C.D. @ 1 \% & 0.255 & 4.975 & 0.599 & 0.685 & 185.44 & 5.283 & 0.048 \\
\hline
\end{tabular}

Seed Treatments $(\mathrm{T})$

$\mathrm{T}_{1}$ :Control (untreated)

$\mathrm{T}_{2}$ : Polymercoat @ $3 \mathrm{ml} / \mathrm{kg}$ of seeds

$\mathrm{T}_{3}$ : Carbendazim @ $2 \mathrm{~g} / \mathrm{kg}$ of seeds

$\mathrm{T}_{7}$ : Polymercoat @ $3 \mathrm{ml} / \mathrm{kg}+$ Saaf @ $3 \mathrm{~g} / \mathrm{kg}$ of seeds

$\mathrm{T}_{8}$ : Polymercoat@3 ml /kg + VitavaxPower@3 g/kg+Pseudomonas fluorescens@30 g/kg of seeds

$\mathrm{T}_{9}$ : Polymercoat@ $3 \mathrm{ml} / \mathrm{kg}+$ Saaf @ $3 \mathrm{~g} / \mathrm{kg}+$ Pseudomonas fluorescens@30 g/kg of seeds 
The treatment with Polymercoat @ $3 \mathrm{ml} / \mathrm{kg}$ of seeds + Saaf @ $3 \mathrm{~g} / \mathrm{kg}$ of seeds + Pseudomonas fluorescens @ $30 \mathrm{~g} / \mathrm{kg}$ of seeds $\left(\mathrm{T}_{9}\right)$ recorded higher field emergence $(98.67$ \%) followed by Polymercoat @ $3 \mathrm{ml} / \mathrm{kg}+$ Vitavax Power@3 g/kg + P. fluorescens @ $30 \mathrm{~g} / \mathrm{kg}$ of seeds $(97.33 \%)$ while, untreated seeds recorded minimum field emergence (90.67\%). This might be due to suppression of the activity of soil borne pathogens or fungi by seed treatment and improved seed germination, vigour and field emergence which facilitated the emergence and establishment of healthy seedlings. Similar findings were confirmed earlier by Dubey et al., (2011) in mung bean who noticed an increase in seed germination due to combined seed treatment of Trichoderma virens and carboxin in green gram under field conditions.

In the present study, significantly higher plant height $(70.98 \mathrm{~cm})$ and number of branches per plant (16.07) was observed in seeds treated with Polymercoat @ $3 \mathrm{ml} / \mathrm{kg}$ of seeds + Saaf @ $3 \mathrm{~g} / \mathrm{kg}$ of seeds + Pseudomonas fluorescens@30 g/ kg of seeds ( $\left.\mathrm{T}_{9}\right)$ followed by Polymercoat @ $3 \mathrm{ml} / \mathrm{kg}+$ VitavaxPower @ $3 \mathrm{~g} / \mathrm{kg}+P$. fluorescens @ $30 \mathrm{~g} / \mathrm{kg}$ of seeds $(67.01 \mathrm{~cm}$ and 15.20 respectively).This may be mainly due to efficient accumulation of photosynthates in the vegetative plant parts. These findings are in agreement with the results obtained by Chikkanna et al., (2000) in cowpea and groundnut, Shakuntala (2010) in Sunflower, Vinodkumar et al., (2013) and Anathi et al., (2015) in redgram.

There was no significant difference between treatments with respect to days to $50 \%$ flowering and days to maturity.

Significant difference among the seed treatments was observed with respect to yield attributes. Among the treatments, Polymercoat@ $3 \mathrm{ml} / \mathrm{kg}+$ Saaf @ $3 \mathrm{~g} / \mathrm{kg}+P$. fluorescens @ $30 \mathrm{~g} / \mathrm{kg}$ of seeds recorded significantly highest number of pods per plant and seeds per pod (18.80 and 12.60) over untreated control (11.60 and 8.53).The increase in number of pods may be due to the more number of branches per plant, decreased flower drop, increased pod setting, nutrient mobilization, nutrient uptake, release of plant growth promoting substances by microbial inoculants and antagonistic activity against pathogens. Similar response due to seed treatment was observed by Tripathi and Singh (1991), Kanti et al., (2013) and Narayanan et al., (2017) in blackgram.

Seed treatments gave significantly higher seed yield per plant and seed yield per plot over control (4.20 g and $0.439 \mathrm{~kg})$. Polymer coating with Saaf $+P$. fluorescens $\left(\mathrm{T}_{9}\right)$ recorded the maximum seed yield per plant and per plot $(6.43 \mathrm{~g}$ and $0.601 \mathrm{~kg})$ followed by polymer coating with VitavaxPower $+P$. fluorescens $\left(\mathrm{T}_{8}\right)(6.23 \mathrm{~g}$ and $0.599 \mathrm{~kg})$.The increase in per plant yield mass may be attributed to good plant growth and development of the seeds promoted by polymer coating, fungicide and bioagents. Plant growth promoting substances secreted by microorganism helped in various metabolic activities and reduction of pathogens and in the proliferation of benefical organisms in the rhizosphere which led to higher number of branches and number of pods per plant which in turn led to higher seed yield per plant. Similar findings due to seed treatments were observed by Kawale et al., (1989), Tripathi and Singh (1991), Chikkanna et al., (2000), Shakuntala et al., (2010) and Vinodkumar et al., (2013) and Kanti et al., (2013).

There was a significant improvement in seed yield per hectare in the seed treatments with polymercoat @ $3 \mathrm{ml} / \mathrm{kg}+$ Saaf @ $3 \mathrm{~g} / \mathrm{kg}+P$. fluorescens@30 g/kg of seeds (695 kg) followed by Polymercoat @ 3 ml/kg of seeds + Vitavax power @ $3 \mathrm{~g} / \mathrm{kg}$ of seeds + 
Pseudomonas fluorescens@ $30 \mathrm{~g} / \mathrm{kg}$ of seeds $\left(\mathrm{T}_{8}\right)(692 \mathrm{~kg})$ as compared to untreated control $(508 \mathrm{~kg})$. The increased yield was attributed to better plant establishment with suppression of seed borne diseases. Similar studies were conducted by Narayanan et al., (2017) in black gram who reported that seeds fortified with $\mathrm{MgSO}_{4}+$ polykote + carbendazim + dimethoate + bioinoculant $(P$. fluorescens $)+$ Rhizobium + Azophos + pelleting with DAP recorded higher seed yield and other parameters when compared to control. Similar findings were also observed by Rajeswari and Meena (2009) in soybean.

The probable reason for such findings was due to more number of pods per plant and seed yield per plant which in turn led to higher yield per hectare. Increase in yield may be attributed to extensive root development and better uptake translocation of nitrogen and phosphorous towards above ground parts. Similar results were also reported by Chikkanna et al., (2000), Shakuntala et al., (2010) and Vinodkumar et al., (2013).

The data (Table 2) on seed quality parameters viz., 100 seed weight (g),germination $(\%)$,shoot length $(\mathrm{cm})$, root length $(\mathrm{cm})$, seedling vigour index, seedling dry weight (mg/10 seedlings)and electrical conductivity $\left(\mathrm{dSm}{ }^{-1}\right)$. The treatment with Polymercoat @ 3 $\mathrm{ml} / \mathrm{kg}$ of seeds + Saaf @ $3 \mathrm{~g} / \mathrm{kg}$ of seeds + Pseudomonas fluorescens @ $30 \mathrm{~g} / \mathrm{kg}$ of seeds $\left(\mathrm{T}_{9}\right)$ recorded highest 100 seed weight $(3.947$ g),seed germination (98.67 \%),shoot length $(16.91 \mathrm{~cm})$, root length $(18.18 \mathrm{~cm})$, seedling dry weight (189.77 mg/10 seedlings), seedling vigour index (3462) and lowest electrical conductivity $\left(0.787 \quad \mathrm{dSm}^{-1}\right)$ and it was followed by Polymercoat @ $3 \mathrm{ml} / \mathrm{kg}$ of seeds + Vitavax power @ $3 \mathrm{~g} / \mathrm{kg}$ of seeds + Pseudomonas fluorescens @ $30 \mathrm{~g} / \mathrm{kg}$ of seeds $\left(\mathrm{T}_{8}\right)$ with 100 seed weight, germination, shoot length, root length, seedling dry weight, seedling vigour index and electrical conductivity of $3.862 \mathrm{~g}, 98.33 \%, 16.83 \mathrm{~cm}$, $18.03 \mathrm{~cm}, 3427$ and $0.797 \mathrm{dSm}^{-1}$, respectively as compared to control $\left(\mathrm{T}_{1}\right)$.

These results are in agreement with the findings of Anathi et al., (2015) in red gram reported that the seed hardening with 100 ppm $\mathrm{ZnSo}_{4}$ and coating with polymer @ $3 \mathrm{ml}$ $\mathrm{kg}^{-1}$ of seed that were added with bavistin@ $2 \mathrm{~g} \mathrm{~kg}^{-1}$ and imidacloprid @ $1 \mathrm{ml} \mathrm{kg}^{-1}$ of seed along with $P$. fluorescens@ $10 \mathrm{~g} / \mathrm{kg}$ and Rhizobium) recorded highest seed germination per cent than control. Similar trend was noticed with 100 seed weight (3.947 g), germination percentage (98.67), shoot length $(16.91 \mathrm{~cm})$, root length $(18.18$ $\mathrm{cm})$, seedling dry weight of $(189.77 \mathrm{mg})$ and less electrical conductivity $\left(0.787 \mathrm{dSm}^{-1}\right)$ as compared to untreated. Similar findings were also reported by Sujatha and Ambika (2016) in black gram, Ovalesha et al., (2017) in cowpea and Dolas et al., (2018a) in mung bean.

The increase in 100 seed weight in treated seeds may be due to the inhibition of activity of pathogen resulted in more dry matter production and availability of photosynthates for sink which ultimately resulted in more seed weight. Similar findings were observed by Tripathi and Singh (1991), Anuja and Aneja (2000), Taywede et al., (2002) and Rezende et al., (2003) in soybean. Desai et al., (1997) reported that high frazzle increases the membrane damage, disturbance of certain enzyme activity responsible for degradation of macromolecules into micro molecules within the seed and other cell structures and thus higher electrical conductivity in untreated seeds.

From the results of this investigation, it can be concluded that seeds treated withPolymercoat @ $3 \mathrm{ml} / \mathrm{kg}$ of seeds + Saaf @ $3 \mathrm{~g} / \mathrm{kg}$ of seeds + Pseudomonas fluorescens @ $30 \mathrm{~g} / \mathrm{kg}$ of seeds could be advocated for better field 
performance and seed quality parameters, so as to get higher seed yield with good quality seeds.

\section{References}

Anonymous, 2018, Agricultural statistics at a glance, GOI. Ministry of Agriculture and farmer's welfare, Dept. www.indiastat.com. p. 37.

Anathi M, Selvaraju P and Srimathi P, 2015, Effect of seed treatment on seed and seedling quality characters in redgram Cv. Co ( $\mathrm{Rg})$ 7. International Journal of Science and Nature, 6(2): 205-208.

Anuja, G and Aneja, K R, 2000, Field efficacy of seed dressing chemicals on seedling emergence, seed yield and seed weight in soybean. Seed Research, 28: 54-58.

Baldev, B, Ramanujan, S and Jain, H K, 2003, Chemical composition of green gram. Pulse Crops, 1: 363.

Chikkanna C S, Timmegouda and Ramesh R, 2000, Hydrophilic polymer seed treatment on seed quality and yield in finger millet, cowpea and groundnut. Seeds and Farms, 85: 39-45.

Desai, B B, Kotecha, P M, Shalunke, D K, 1997, Seed hand book-Biology, Production, Processing and Storage. Marcel Dekker. Inc. New York. 473496.

Dolas R M, Gawade S B and Kasture M C, 2018a, Studies of seed borne micoflora of mung bean and its effect on seed germination and seedling vigour index. International Journal of Chemical Studies, 6(5): 802-806.

Dubey S C, Bhavani R and Singh B, 2011, Integration of soil application and seed treatment formulations of Trichoderma species for management of wet root rot of mungbean caused by Rhizoctonia solani. Pest Management Science, 67: 1163-1168.
John, M P, 1991, The mung bean. Oxford and IBH publications, New Delhi (India).

Kanti, V M, Bala, N, Rai, P K, Lavanya, G R and Babu, S, 2013, Combined and Individual action of bioagents and fungicides on seed yield of soybean (Glycine max L. Merrill). New York Science Journal, 6(4): 32-35.

Kawale, B A, Kurundkar, B P and Thombre, P A, 1989, Effect of fungicide and insecticide, weedicides on emergence and yield of soybean (Glycine max (L.) Merril). Journal of Oil Seed Research, 6: 357-359.

Narayanan G S, Prakash M, Rajesh V and Kumar, 2017, Effect of integrated seed treatments on growth, seed yield and quality parameters in blackgram [Vigna mungo (L.) Hepper]. Indian Jounal of Agricultural Research, 51(6): 556-561.

Ovalesha M A, Yadav B and Kumar Rai, 2017, Effects of polymer seed coating and seed treatment on plant growth, seed yield and quality of cowpea (Vigna unguiculata). Journal of pharmacognosy and Phytochemistry, 6(4): 106-109.

Rajeswari, B and Meena, KVS, 2009, Bioagents and fungicides for the management of seed and seedling diseases of soybean. Indian Journal of Plant Protection, 37(2): 121-131.

Rezende, P M, Machado, J C, Gris, C F, Gomes, L L, Botrel, E P C and Machado, J, 2003, Effect of dry soil sowing and seeds treatment on emergence, yields grains and characteristics of soybean. Ciencae Agrotecnologia, 27(1): 76-83.

Sangamesh A and Patil B L, 2018, Economics of cost of cultivation of green gram in Gadag district of Karnataka. Journal of Pharmacognosy and Phytochemistry, 7(3): 1206-1210.

Santoshi, P, Lakpale, N, Tiwari, P K and Pradhan, A, 2017, Effect of seed 
treatment and seed borne mycoflora on vigour of mung bean [Vigna radiata (L.) Wilczek] Grown in Agro Climatic Zones of Chhattisgarh, India. Int.J.Curr.Microbiol.App.Sci, 6 (11): 1946-1954.

Shakuntala N M, Vyakaranahal B S, Shankergoud I, Deshpande V K, Pujari B T and Nadaf H L, 2010, Effect of seed polymer coating on growth and yield of sunflower hybrid RSFH-130. Karnataka Journal of Agricultural Sciences, 23(5): 708-711.

Sujatha K and Ambika K, 2016, Designer seed for enhancement of yield in black gram (Vigna mungo L.). Indian Journal of Agricultural Research, 50(5): 479-482.

Sundarrajan N, Nagraju S, Venktataraman S and Jaganath M H, 1972, Design and analysis of field experiments. M.Sc. (Agri) Thesis. University of Agricultural Sciences, Bangalore (India).
Taywede, A S, Potolukhes, S R, Shivankar, R $\mathrm{S}$, Sonone, J S and Naphade, R S, 2002, Effect of seed dressing chemicals and Rhizobium inoculation on the yield of soybean [Glycine max. (L.) Merill]. LegumeResearch, 25(4): 297-298.

Tripathi, D P, and Singh, B R, 1991, Mycoflora of soybean seed and their control. Madras Agricultural Journal, 78(1-4): 130-132.

Vanangamudi K, Srimathi P, Natarajan N and Bhaskaran M, 2003, Current scenario of seed coating polymer. ICAR - Short Course on Seed Hardening and Pelleting Technologies for Rainfed or Garden Land Ecosystems, pp: 80-100.

Vinodkumar S B, Vyakaranahal B S, Dhananjaya P, Hipparagi Y and Asha A M, 2013, Effect of seed polymer coating on field performance and quality of pigeonpea (Cajanus cajan (L.) Mill sp). Environment and Ecology, 31(1): 43-46.

\section{How to cite this article:}

Heena Kouser, H. M., R. B. Jolli, Jagadish Hosamani and Jamadar, M. M. 2020. Effect of Polymercoat, Fungicides and Bioagent Treatment on Plant Growth, Seed Yield and Quality of Green Gram [Vigna radiata (L.) Wilczek]. Int.J.Curr.Microbiol.App.Sci. 9(12): 1912-1920. doi: https://doi.org/10.20546/ijcmas.2020.912.227 